\title{
Increased assimilates in lily yearling bulblets by fertilizer supplement of magnetic nano-composite
}

\author{
Seyedeh-Somayyeh Shafiei-Masouleh
}

\begin{abstract}
In bulb production period, the promotion of photosynthesis and, consequently, increased synthesis of carbohydrates have the particular importance to enhance the size and quality of the bulbs. The aim of this study was to investigate the effects of chitosan and magnetism on the synthesis of photosynthetic compounds. Magnetic nano-composite (MN) and carboxymethyl chitosan (CM) during the production period of yearling bulblet were used as experimental materials. The results showed that $\mathrm{MN}\left(15 \mathrm{mg} \mathrm{L}^{-1}\right)$ had the highest effects on the amounts of photosynthetic pigments. Compared to other treatments, this treatment had the highest effect on starch, while the soluble carbohydrates and amylase activities showed the highest amount with CM (5 to $\left.15 \mathrm{mg} \mathrm{L}^{-1}\right)$. However, due to the importance of starch in bulb size and quality, $\mathrm{MN}$ with a concentration of $15 \mathrm{mg} \mathrm{L}^{-1}$ is recommended.
\end{abstract}

Keywords: Lilium, bulb, magnetism, photosynthesis, soluble carbohydrates.

\section{Introduction}

Researchers' aims are to increase lily plant growth and development by creating proper conditions to achieve the best quality and performance of yearling bulblets (Kim et al., 2007a). Carbon allocation in plants is important; it is influenced by various factors such as the level of photosynthetic products, size and number of competitor sinks (flowers, seeds, fruits, bulbs and tubers, etc.) and their positions in the plant, the potential of the primary storage in leaves and re-translocation in plants. Understanding effective components in the initiation and developments of organs and source-sink balance to set allocating assimilates are necessary. The chlorophyll level of leaf affects photosynthesis, and the ratio of chlorophyll $a$ and $b$ are the best indicator to understand the photosynthetic capacity and gives direct information about the activity of enzymes involved in photosystem II (Răcuciu and Creangă, 2007b; Răcuciu et al., 2009). Iron $(\mathrm{Fe})$ deficiency reduces the photosynthetic pigments. The uptake of $\mathrm{Fe}$ in alkaline soils is difficult (Thoiron and Briat, 1999). The use of chelating compounds to eliminate the problems of $\mathrm{Fe}$ uptake by plants is useful (Abadía et al., 2011). Magnetic fluids at proper concentration have a positive effect on plant photosynthetic capacity. Iron ions in the structure of the magnetic fluids can be an important source of $\mathrm{Fe}$ for plants (Răcuciu and Creangă, 2007b).
Zhang et al. (2018) suggested that $\mathrm{Fe}_{3} \mathrm{O}_{4}$ nanoparticles might enhance $\mathrm{Fe}$ (II) - $\mathrm{Fe}$ (III) electron transfer. Magnetite $\left(\mathrm{Fe}_{3} \mathrm{O}_{4}\right)$ has been approved biocompatibility (Răcuciu et al., 2009).

We can categorize nanofertilizers according their roles as 1) macronutrients, 2) micronutrient and 3) the carrier of macronutrient. Some nanomatrials with above-mentioned third role has a layer of chitosan around nano particles (Kah et al., 2018). Chitosan is a deacetylated derivative of chitin. It is a natural polymer and will be biodegraded by biological agents and it is environment-friendly used in agriculture (Wu and Liu, 2008). We can enhance the biocompatibility and biodegradability of chitosan by conversion to nanochitosan (Chandra et al., 2015; Siddaiah et al., 2018; Hassan et al., 2018). The in vitro application of chitosan with proper concentrations in Vitis vinifera L. stimulates plant photosynthesis and causes plant growth with increasing the biomass of roots and shoots. However, so far researchers have not measured the effects of chitosan as nanoparticles and with magnetic features on plant growth.

If you know, in geophytes, the quality of the bulbs is assayed based on carbohydrates, especially based on the amount of starch and amylases of the bulb, and it is clear that photosynthesis affects them. The aim of this research was to investigate effects of magnetism and chitosan on the photosynthesis performance of the yearling bulblet in the oriental lily, Arabian Red.

Department of Genetics and Breeding, Ornamental Plants Research Center (OPRC), Horticultural Sciences Research Institute (HSRI), Agricultural Research, Education and Extension (AREEO), Mahallat, Iran. Corresponding Author: shafiee.masouleh@areeo.ac.ir; shafyii@gmail.com ${ }^{0000-0001-5455-0970}$ 


\section{Material and Methods}

\section{Plant materials}

After scaling 150 Lilium bulbs 'Arabian Red' (Oriental group; Van Den Bos Co., The Netherlands), and producing scale bulblets $(\sim 2$ bulblets per scale and $\sim 70$ bulblets per mother bulbs) (Shafiee-Masouleh et al., 2014), scale bulblets were vernalized at $3-5{ }^{\circ} \mathrm{C}$ in a house refrigerator for two months and finally planted in $450 \mathrm{~cm}^{3}$ polystyrene cups (cocopeat: perlite; 1:2). A greenhouse study was designed at greenhouse $\left(14{ }^{\circ} \mathrm{C} / 10{ }^{\circ} \mathrm{C}\right.$ day/night and $9 \mathrm{~h}$ photoperiods for 35 days, and then daily temperature $22 \pm 10^{\circ} \mathrm{C}$ and 4 HPS lamps in cloudy days), in a glass greenhouse. The treatments of plants (grown from 297 uniform scale bulblets) were carried out using experimental compounds since days 76 to 162 (harvest of yearling bulblets). These compounds included Magnetic nano-composite (MN; 1, 2.5, 5, 10 or $15 \mathrm{mg} \mathrm{L}^{-1}$ in Hoagland (Hoagland and Arnon, 1950) solution without Fe salt), or carboxymethyl chitosan (CM; 1, 2.5, 5, 10 or 15 $\mathrm{mg} \mathrm{L}^{-1}$ in Hoagland solution with Fe sulfate). Moreover, the control treatment was the Hoagland solution with iron sulfate (IS) (Kim et al., 2007a, 2007b; Niedziela et al., 2008).
Preparation of carboxymethyl chitosan and magnetic nano-composite

The solubility of chitosan (low molecular weight 100,000-300,000; Acros, Belgium) was increased by carboxymethylation of chitosan with alcoholic monochloroacetic acid solution (see Shafiee-Masouleh et al., 2014). The Na salt-free CM was analyzed with an infrared spectroscopy (IR; IR-470, Shimadzu, Kyoto, Japan; Figure 1).

Magnetite $\left(\mathrm{Fe}_{3} \mathrm{O}_{4}\right)$ nano-particle synthesis was conducted according to Kang et al. (1996). The details of synthesis with $\mathrm{FeCl}_{3}$ (Merck, Germany; $5.2 \mathrm{~g}$ ) and $\mathrm{FeCl}_{2} .4 \mathrm{H}_{2} \mathrm{O}$ (Merck, Germany; $3.14 \mathrm{~g}$ ) were described by Shafiee-Masouleh et al. (2014) to produce black participate in alkaline conditions and deoxygenating by $\mathrm{N}_{2}$.

$\mathrm{MN}$ was produced by encapsulation of $\mathrm{Fe}_{3} \mathrm{O}_{4}$ with $\mathrm{CM}$ according to Chang and Chen (2005). This process was based on sonication method in the saline phosphate buffer and carbodimiide (cyanamide, $\mathrm{CH}_{2} \mathrm{~N}_{2}$, Merck, Germany), which was described by Shafiee-Masouleh et al. (2014) in detail. The size and crystal structure of magnetic nanocomposite were analyzed by X-ray (XRD) based on DebyeScherrer equation (Figure 2).

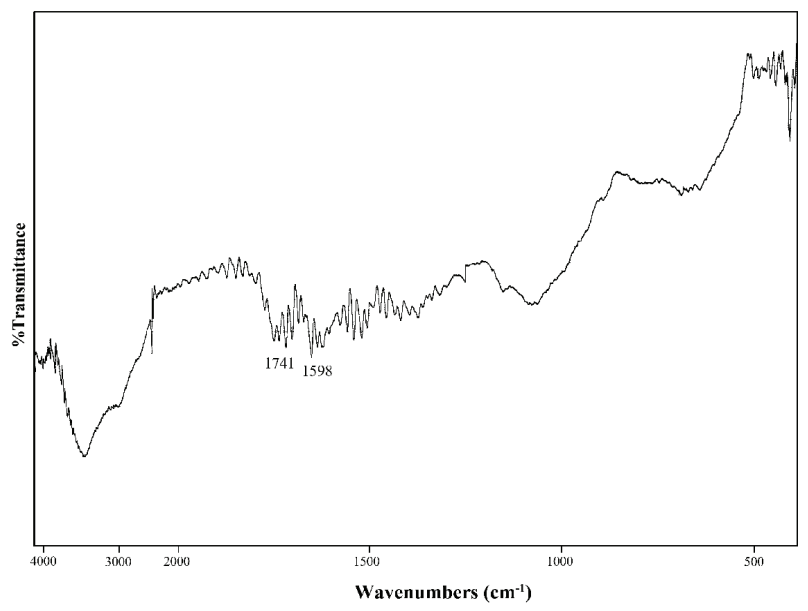

Figure 1. IR spectra for carboxymethyl chitosan. $1741 \mathrm{~cm}^{-1}$ is the wave number for $\mathrm{C}=\mathrm{O}$ in the carboxyl group $(-\mathrm{COOH})$ and $1598 \mathrm{~cm}^{-1}$ shows $\mathrm{N}-\mathrm{H}$ for an amino group $\left(-\mathrm{NH}_{2}\right)$.

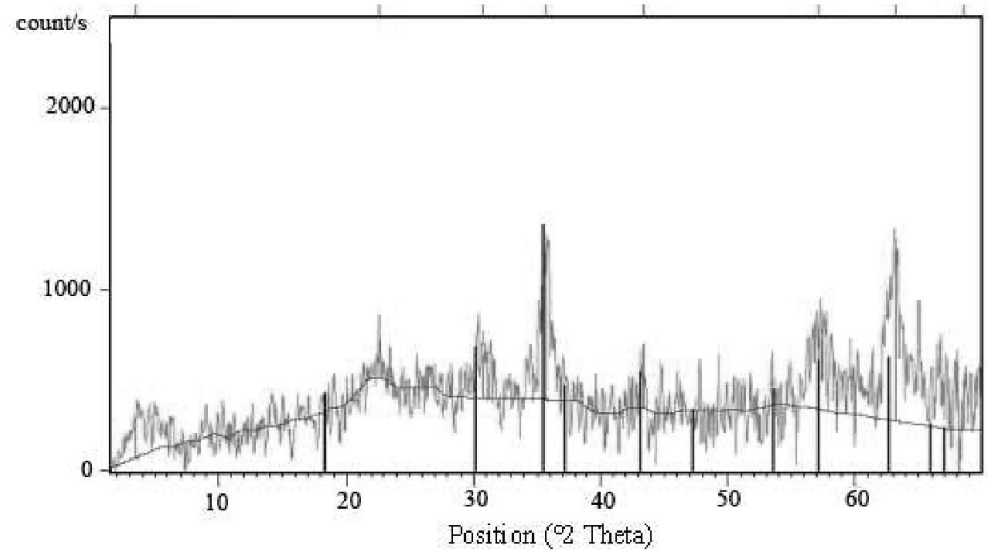

Figure 2. Crystal structure of magnetic nano-composite. Peaks shows cubic structure of $\mathrm{Fe}_{3} \mathrm{O}_{4}$, and obtuse angle $2 \theta=21-23$ shows crystal structure of chitosan and it determines coating $\mathrm{Fe}_{3} \mathrm{O}_{4}$ with carboxymethyl chitosan. Based on Debye-Scherrer, nanoparticles size is $10.4 \mathrm{~nm}$. 


\section{Biochemical and physiological assays}

\section{Starch}

According to Castro and Clément (2007), extraction of starch from yearling bulblet tissues was performed with sodium phosphate buffer $0.1 \mathrm{M}(\mathrm{pH} 7.5)$, and then the diethylsulfoxide solution (1 mL $8 \mathrm{~N}$ hydrochloric acid: 4 $\mathrm{ml}$ of DMSO) was added to supernatant in the dark. Finally, absorption was read by spectrophotometer against control $(1000 \mu \mathrm{L}$ of acid dioxin-disulphoxide solution and $500 \mu \mathrm{L}$ of alcohol) at $600 \mathrm{~nm}$.

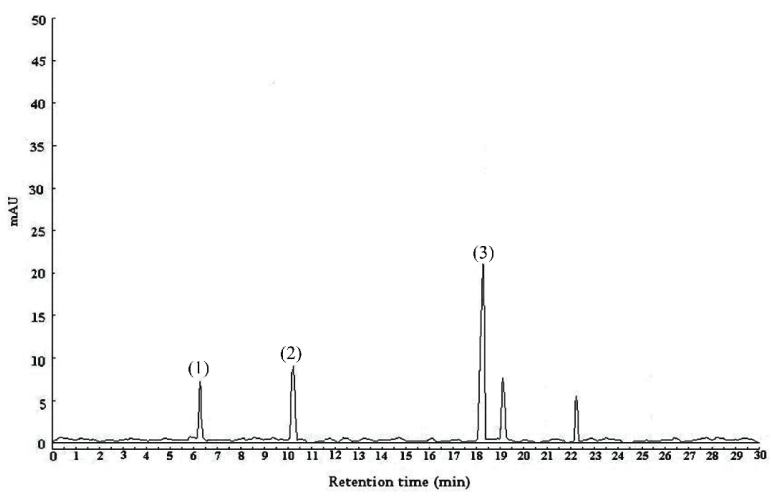

A
Soluble sugars (glucose, fructose and sucrose)

According to Shin et al. (2002), the extraction of soluble carbohydrates (sucrose, glucose and fructose) was conducted with $80 \%$ ethanol. Measurements were performed by the

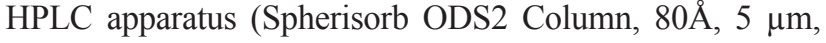
$4.6 \mathrm{~mm}$ X $150 \mathrm{~mm}, \mathrm{~L} / \mathrm{pkg}$, Silica based C18 reversed phase; WATERS; Hungary) was used with an UV detector in 320 $\mathrm{nm}$ (Figure 3). The mobile phase consisted of sodium citrate buffer with pH 5.5 and acetonitrile (HPLC purity, Merck, Germany) at a ratio of 1:99 at a speed of $0.1 \mathrm{~mL} \mathrm{~min}{ }^{-1}$. Based on the retention time and using standard samples, the type and amount of sugars in unknown specimens were determined (Gomis et al., 2001).

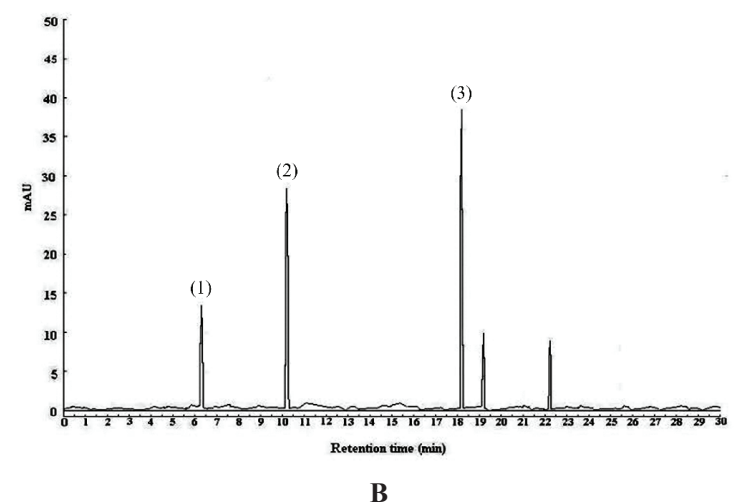

B

Figure 3. Chromatography peaks (HPLC) of soluble carbohydrates. A) From yearling bulblets of plants treated with $1 \mathrm{mg} \mathrm{MN}^{-1}$ and B) Plants treated with $5 \mathrm{mg} \mathrm{CM} \mathrm{l}^{-1}$. 1) Fructose, 2) Glucose and 3) Sucrose with UV detector.

$\alpha$-amylase and $\beta$-amylase activity

For extraction of amylase enzymes, $1 \mathrm{~g}$ yearling bulblet tissue was added to $3 \mathrm{~mL}$ of a buffer containing HEPS-NaOH buffer ( $\mathrm{pH}$ 7.5), $20 \mathrm{mM}$ magnesium chloride, $10 \mathrm{mM}$ isoascorbic acid, 1 mM EDTA, $10 \mathrm{mM} \beta$-mercaptoethanol and $2 \%(\mathrm{w} / \mathrm{v})$ polyvinylpyrrolidone. All extracting steps were carried out at $4{ }^{\circ} \mathrm{C}$ and then homogenized with the vortex and centrifuged at $2000 \times \mathrm{g}$ at $4{ }^{\circ} \mathrm{C}$ and the supernatant was filtered with a $0.45 \mu \mathrm{m}$ filter, and for enzyme measurement was maintained at $4{ }^{\circ} \mathrm{C}$ (Shin et al., 2002).

The measurement of $\alpha$-amylase activity was performed according to Nielsen et al. (1997) by spectrophotometer (Spectrophotometer; DESAGA GmbH, D-6900, Heidelberg, Germany) at $405 \mathrm{~nm}$. The activity level of one unit $\alpha$-amylase was explained in units per milliliter of enzyme per gram of dry weight.

To measure the activity of $\beta$-amylase, extracts were prepared according to Doehlert et al. (1982) and Shin et al. (2002) and absorption changes of the reaction product (maltose) were read against control (extract-free solution) and based on the standard curve using a spectrophotometer (Spectrophotometer; DESAGA GmbH, D-6900, Heidelberg, Germany) at $540 \mathrm{~nm}$. The activity level of a unit of $\beta$-amylase required to produce a $\mu \mathrm{M}$ maltose per minute was defined as mg unit of enzyme per gram of dry weight.

\section{Photosynthetic pigments}

The photosynthetic pigments were extracted from $0.5 \mathrm{~g}$ tissue of new complete leaves with $8 \mathrm{~mL}$ of $96 \%$ ethanol for 24 hours under a gas hood at room temperature $\left(25-30{ }^{\circ} \mathrm{C}\right)$ at dark conditions (Lichtenthaler, 1987). Absorption of the extracts was measured and recorded in three wavelengths of 470, 668 and $664 \mathrm{~nm}$ against solvent (96\% ethanol) as a control with a spectrophotometer (Lichtenthaler, 1987; Lichtenthaler and Buschmann, 2001).

\section{Statistical analysis}

A completely randomized design with ten chitosan treatments (five concentrations of $\mathrm{CM}$ and five concentrations of $\mathrm{MN}$ ) and one treatment of iron sulfate as the control in nine replications was used to study treatments. Each experimental unit consisted of three cups containing one scale bulblet each (297 experimental units in total). Eight plants were randomly sampled after 169 days.

Variance analysis was performed with SAS software 9.1. Means were compared by Tukey test (HSD) at the levels of $\mathrm{P}$ $\leq 0.01$ or $\mathrm{P} \leq 0.05$ according to the variance analysis. 


\section{Results}

\section{Photosynthetic pigments and performance}

Fifteen $\mathrm{mg} \mathrm{MN} \mathrm{L}^{-1}$ caused the greater content of chl $a^{1}$ compared to $1 \mathrm{mg} \mathrm{MN} \mathrm{L}^{-1}(3$ times, $\mathrm{P} \leq 0.05)$ and other concentrations of this supplement. All concentrations of $\mathrm{CM}$ showed no significant difference in chl $a$, while $\mathrm{MN}$ with increasing concentrations of 1 to $15 \mathrm{mg} \mathrm{L}^{-1}$ approximately $200 \%$ increased the content of chl $a$, in other words, between different concentrations of $\mathrm{MN}$, significant differences were observed (Table 1).

In comparing the two chitosan supplements ( 5 levels each and control), the amount of leaves chl $b, 137$ days after planting scale bulblets was similar to results of chl $a$. The content of chl $b$ in the plants treated with daily treatment with $15 \mathrm{mg} \mathrm{MN} \mathrm{L}^{-1}$ has a significant difference $(\mathrm{P} \leq 0.05)$ with $15 \mathrm{mg} \mathrm{CM} \mathrm{L}^{-1}$ and $10 \mathrm{mg} \mathrm{MN} \mathrm{l}^{-1}$. (Table 1). Ratio of chl $a / b$ did not show significant changes influenced by different treatments (Table 1).

Furthermore, carotenoids had a similar trend with total chl $(\mathrm{chl} a+b)$ influenced by magnetic and non-magnetic chitosan 137 days after planting of scale bulblets. The content of carotenoid and chl $a+b$ in a concentration of 15 $\mathrm{mg} \mathrm{MN} \mathrm{L}{ }^{-1}$ had no significant difference with $15 \mathrm{mg} \mathrm{CM} \mathrm{L}^{-1}$ compared to $\mathrm{chl} a+b$ (Table 1). The ratio of $\mathrm{chl} /$ carotenoid as a photosynthetic indicator had no difference between two chitosan supplements in different concentrations and in the control (Table 1).

Correlation coefficients between the photosynthetic pigments and indicators show that $\operatorname{chl} a \operatorname{chl} b$, total chl and carotenoids have very significant positive correlation together. Two photosynthetic indicators of chl $a / b$ and total chl/carotenoid have a significant negative correlation together (Table 2).

Table 1. CM and MN effects on photosynthetic pigments of leaf tissues ( $\mathrm{mg} \mathrm{g}^{-1}$ dry weight) of 137-day plants in yearling bulblet production period.

\begin{tabular}{|c|c|c|c|c|c|c|}
\hline Treatments & $\mathbf{C h l} \boldsymbol{a}$ & $\mathbf{C h l} \boldsymbol{b}$ & $\mathbf{C h l}(\boldsymbol{a}+\boldsymbol{b})$ & $\mathbf{C h l}(\boldsymbol{a} / \mathbf{b})$ & Carotenoid & Chl/Carotenoid \\
\hline IS & $0.64 \pm 0.02 \mathrm{ab}$ & $0.32 \pm 0.02 \mathrm{ab}$ & $0.95 \pm 0.04 \mathrm{ab}$ & $2.02 \pm 0.04$ & $0.15 \pm 0.002 \mathrm{ab}$ & $6.38 \pm 0.22$ \\
\hline $\mathrm{CM} 1$ & $0.9 \pm 0.02 \mathrm{ab}$ & $0.42 \pm 0.06 \mathrm{ab}$ & $1.22 \pm 0.15 \mathrm{ab}$ & $1.96 \pm 0.07$ & $0.21 \pm 0.005 \mathrm{ab}$ & $6.3 \pm 0.16$ \\
\hline $\mathrm{CM} .5$ & $0.62 \pm 0.2 \mathrm{ab}$ & $0.32 \pm 0.12 \mathrm{ab}$ & $0.94 \pm 0.34 \mathrm{ab}$ & $1.85 \pm 0.1$ & $0.16 \pm 0.05 \mathrm{ab}$ & $6.76 \pm 0.73$ \\
\hline $\mathrm{CM} 5$ & $0.6 \pm 0.2 \mathrm{ab}$ & $0.29 \pm 0.1 \mathrm{ab}$ & $0.89 \pm 0.31 \mathrm{ab}$ & $1.88 \pm 0.18$ & $0.2 \pm 0.02 \mathrm{ab}$ & $7.3 \pm 1.06$ \\
\hline $\mathrm{CM} 10$ & $0.77 \pm 0.06 \mathrm{ab}$ & $0.38 \pm 0.02 \mathrm{ab}$ & $1.16 \pm 0.08 \mathrm{ab}$ & $2.02 \pm 0.07$ & $0.19 \pm 0.003 \mathrm{ab}$ & $6.09 \pm 0.32$ \\
\hline CM15 & $0.5 \pm 0.05 \mathrm{~b}$ & $0.24 \pm 0.03 \mathrm{~b}$ & $0.74 \pm 0.08 \mathrm{a}$ & $2.08 \pm 0.02$ & $0.12 \pm 0.02 \mathrm{~b}$ & $5.92 \pm 0.17$ \\
\hline MN1 & $0.36 \pm 0.06 \mathrm{~b}$ & $0.28 \pm 0.004 \mathrm{ab}$ & $0.82 \pm 0.03 \mathrm{ab}$ & $1.97 \pm 0.05$ & $0.14 \pm 0.01 \mathrm{ab}$ & $5.87 \pm 0.13$ \\
\hline MN2.5 & $0.5 \pm 0.14 \mathrm{~b}$ & $0.25 \pm 0.06 \mathrm{ab}$ & $0.74 \pm 0.2 \mathrm{~b}$ & $1.97 \pm 0.06$ & $0.13 \pm 0.03 \mathrm{~b}$ & $5.77 \pm 0.06$ \\
\hline MN5 & $0.9 \pm 0.13 \mathrm{ab}$ & $0.44 \pm 0.08 \mathrm{ab}$ & $1.32 \pm 0.2 \mathrm{ab}$ & $2.02 \pm 0.04$ & $0.18 \pm 0.04 \mathrm{ab}$ & $5.83 \pm 0.11$ \\
\hline MN10 & $0.54 \pm 0.02 \mathrm{~b}$ & $0.18 \pm 0.03 \mathrm{~b}$ & $0.82 \pm 0.03 \mathrm{~b}$ & $1.98 \pm 0.01$ & $0.09 \pm 0.01 \mathrm{~b}$ & $5.66 \pm 0.14$ \\
\hline MN15 & $1.08 \pm 0.05 \mathrm{a}$ & $0.52 \pm 0.03 \mathrm{a}$ & $1.59 \pm 0.08 \mathrm{a}$ & $2.02 \pm 0.04$ & $0.27 \pm 0.02 \mathrm{a}$ & $6.01 \pm 0.11$ \\
\hline ANOVA & $* *$ & $*$ & $* *$ & $n$ & $*$ & $\mathrm{~ns}$ \\
\hline CV\% & 21.62 & 23.43 & 22.75 & 6.72 & 22.86 & 11.78 \\
\hline
\end{tabular}

** Significance at $\mathrm{P} \leq 0.01,{ }^{*}$ significance at $\mathrm{P} \leq 0.05$, ${ }^{\mathrm{ns}}$ not significant based on variance analysis

The means with similar letters in each column are not significant (Tukey's range test, $\mathrm{P} \leq 0.05$ ).

Table 2. Correlation coefficients between the photosynthetic pigments and indicators, 137 days after planting scale bulblets.

\begin{tabular}{|c|c|c|c|c|c|}
\hline Parameters & Chl $\boldsymbol{a}$ & Chl $\boldsymbol{b}$ & Chl $(\boldsymbol{a}+\boldsymbol{b})$ & Chl $(\boldsymbol{a} / \boldsymbol{b})$ & Carotenoid \\
\hline Chl $a$ & 1.00 & & & \\
\hline Chl $b$ & $0.912^{* *}$ & 1.00 & & \\
\hline Chl $(a+b)$ & $0.959^{* *}$ & $0.958^{* *}$ & 1.00 & \\
\hline Chl $(a / b)$ & 0.170 & 0.136 & 0.180 & 1.00 \\
\hline Carotenoid & $0.827^{* *}$ & $0.903^{* *}$ & $0.858^{* *}$ & -0.078 & 1.00 \\
\hline Chl/Carotenoid & 0.031 & 0.067 & 0.032 & $-0.689^{*}$ & 0.353 \\
\hline
\end{tabular}

${ }^{* *}$ Correlation at $\mathrm{P} \leq 0.01,{ }^{*}$ correlation at $\mathrm{P} \leq 0.05$ (two-tailed), $\mathrm{N}=11$ 


\section{Carbohydrates and amylases}

Based on Table 3, it can be observed that the starch content of yearling bulblet tissue in the plants treated with $15 \mathrm{mg} \mathrm{MN} \mathrm{L}^{-1}$ was greater than $\mathrm{CM} 1,2.5,5$ and 15 $\mathrm{mg} \mathrm{L} \mathrm{L}^{-1}$, however it is equal to others. It can be stated that
$1392 \%$ increase in starch content of scale tissue in plants treated with $15 \mathrm{mg} \mathrm{MN} \mathrm{L}^{-1}$ was obtained compared to the lowest treatment effect. Even compared to the highest concentration of CM (15 mg L-1) $294.22 \%$ increase in starch content is observed.

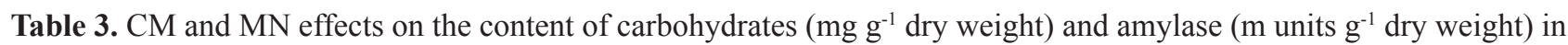
yearling bulblet of lily.

\begin{tabular}{|c|c|c|c|c|c|c|}
\hline Treatment & Starch $^{\mathbf{b}}$ & Sucrose & Glucose & Fructose & $\boldsymbol{\alpha}$-amylase & $\boldsymbol{\beta}$-amylase \\
\hline IS & $758 \pm 243.5 \mathrm{c}$ & $1.87 \pm 0.54 \mathrm{bc}$ & $2.71 \pm 0.21 \mathrm{~d}$ & $2.17 \pm 0.18 \mathrm{~d}$ & $8.4 \pm 0.44 \mathrm{dc}$ & $26.5 \pm 2.67 \mathrm{bc}$ \\
\hline $\mathrm{CM} 1$ & $783 \pm 31.25 \mathrm{c}$ & $2.18 \pm 0.19 \mathrm{abc}$ & $3.16 \pm 0.11 \mathrm{~cd}$ & $2.15 \pm 0.12 \mathrm{~d}$ & $12.37 \pm 1.11 \mathrm{abc}$ & $38.57 \pm 4.28 \mathrm{abc}$ \\
\hline $\mathrm{CM} 2.5$ & $983 \pm 218.75 \mathrm{c}$ & $2.64 \pm 0.32 \mathrm{abc}$ & $4.55 \pm 0.39 \mathrm{abc}$ & $2.44 \pm 0.13 \mathrm{~cd}$ & $14.47 \pm 0.42 \mathrm{ab}$ & $47.33 \pm 3.69 \mathrm{a}$ \\
\hline $\mathrm{CM} 5$ & $3868 \pm 145.12 \mathrm{~b}$ & $3.63 \pm 0.37 \mathrm{a}$ & $5.45 \pm 0.31 \mathrm{a}$ & $2.59 \pm 0.13 \mathrm{abcd}$ & $15.57 \pm 0.54 \mathrm{a}$ & $42.07 \pm 2.61 \mathrm{ab}$ \\
\hline $\mathrm{CM} 10$ & $7326 \pm 1087.5 \mathrm{ab}$ & $2.97 \pm 0.23 \mathrm{ab}$ & $4.58 \pm 0.29 \mathrm{abc}$ & $3.15 \pm 0.13 \mathrm{abc}$ & $14.03 \pm 0.52 \mathrm{ab}$ & $29.1 \pm 2.00 \mathrm{bc}$ \\
\hline $\mathrm{CM} 15$ & $2870 \pm 206.25 \mathrm{~b}$ & $2.38 \pm 0.18 \mathrm{abc}$ & $4.8 \pm 0.26 \mathrm{ab}$ & $3.31 \pm 0.1 \mathrm{a}$ & $12.8 \pm 0.75 \mathrm{ab}$ & $26.7 \pm 2.64 \mathrm{bc}$ \\
\hline MN1 & $9614 \pm 3262.5 \mathrm{ab}$ & $1.24 \pm 0.22 \mathrm{c}$ & $2.79 \pm 0.2 \mathrm{~d}$ & $1.81 \pm 0.16 \mathrm{~d}$ & $7.97 \pm 0.93 \mathrm{~d}$ & $24.37 \pm 1.44 \mathrm{c}$ \\
\hline MN2.5 & $5720 \pm 406.25 \mathrm{ab}$ & $1.26 \pm 0.24 \mathrm{c}$ & $3.04 \pm 0.21 \mathrm{~d}$ & $1.98 \pm 0.12 \mathrm{~d}$ & $8.33 \pm 0.56 \mathrm{~cd}$ & $24.53 \pm 2.78 \mathrm{c}$ \\
\hline MN5 & $6533 \pm 3031.25 \mathrm{ab}$ & $1.85 \pm 0.19 \mathrm{bc}$ & $3.21 \pm 0.13 \mathrm{~cd}$ & $2.5 \pm 0.15 \mathrm{bcd}$ & $10.11 \pm 0.78 \mathrm{bcd}$ & $31.43 \pm 2.84 \mathrm{abc}$ \\
\hline MN10 & $4408 \pm 393.75 \mathrm{ab}$ & $3.097 \pm 0.28 \mathrm{ab}$ & $3.69 \pm 0.14 \mathrm{bcd}$ & $3.25 \pm 0.28 \mathrm{ab}$ & $10.50 \pm 0.61 \mathrm{bcd}$ & $36.7 \pm 3.18 \mathrm{abc}$ \\
\hline MN15 & $11314 \pm 950 \mathrm{a}$ & $2.63 \pm 0.26 \mathrm{abc}$ & $3.85 \pm 0.15 \mathrm{bcd}$ & $3.13 \pm 0.14 \mathrm{abc}$ & $10.77 \pm 0.78 \mathrm{bcd}$ & $38.23 \pm 2.38 \mathrm{abc}$ \\
\hline ANOVA & $* *$ & $* *$ & $* *$ & $* *$ & $* *$ & $*$ \\
\hline CV\% & 39.65 & 21.59 & 10.69 & 10.44 & 10.94 & 14.95 \\
\hline
\end{tabular}

*** Significance at $\mathrm{P} \leq 0.01$ based on variance analysis.

The means with similar letters in each column are not significant (Tukey's range test, $\mathrm{P} \leq 0.05$ )

According to Table 3, all of soluble carbohydrates (sucrose, glucose and fructose) and amylases ( $\alpha$ - and $\beta-)$ showed better responds to $\mathrm{CM}$ concentrations especially concentrations of $2.5-15 \mathrm{mg} \mathrm{L}^{-1}$. However, only concentrations of 10 and $15 \mathrm{mg} \mathrm{MN} \mathrm{L}^{-1}$ (and also $5 \mathrm{mg} \mathrm{L}^{-1}$ for amylases) based on Tukey test were similar to the plants treated to CM.
According to Table 4, no correlations between starch and soluble sugars contents and activities of amylases are observed. The significant positive correlation $(\mathrm{P} \leq 0.01)$ is observed between the amounts of sucrose, glucose and $\alpha$-amylase, $\beta$-amylase. The positive and significant relationship is also observed between activities of two enzymes.

Table 4. Correlation coefficients between carbohydrates of scale tissue of yearling bulblets and amylases

\begin{tabular}{|c|c|c|c|c|c|c|}
\hline Parameters & Starch & Sucrose & Glucose & Fructose & $\boldsymbol{\alpha}$-amylase \\
\hline Starch & 1.00 & & & \\
\hline Sucrose & -0.143 & 1.00 & & \\
\hline Glucose & -0.110 & $0.816^{* *}$ & 1.00 & 1.00 & \\
\hline Fructose & 0.147 & $0.691^{*}$ & $0.610^{*}$ & 0.461 & 1.00 \\
\hline$\alpha$-amylase & -0.305 & $0.811^{* *}$ & $0.903^{* *}$ & 0.207 & $0.675^{*}$ \\
\hline$\beta$-amylase & -0.271 & $0.669^{*}$ & 0.501 & 1.00 \\
\hline
\end{tabular}

${ }^{* *}$ Correlation at $\mathrm{P} \leq 0.01,{ }^{*}$ correlation at $\mathrm{P} \leq 0.05$ (two-tailed correlation), $\mathrm{N}=11$.

According to the results of the correlation between carbohydrates of yearling bulblet scale and amylases, the imported starch and fructose in the stepwise regression model were exported and two soluble sugars (glucose and sucrose) as dependent variables and two $\alpha$ - and $\beta$-amylases were considered as independent variables (Table 5). So that, $81 \%$ of the sucrose content and $90 \%$ of the glucose content affected by the rates of $\alpha$-amylase activity, and $\beta$-amylase had not any significant effect on the content of these sugars, and other factors also remained as unknown. 
Table 5. Relationship between soluble carbohydrates of scale tissue of lily yearling bulblet against amylases ( $\alpha$ - and $\beta$-) with stepwise regression method, $\mathrm{N}=11$ plants.

\begin{tabular}{|c|c|c|c|c|c|c|c|c|}
\hline \multicolumn{9}{|c|}{ Linear model } \\
\hline \multirow{2}{*}{ Variable } & \multicolumn{2}{|c|}{ B } & \multicolumn{2}{|c|}{$\boldsymbol{\beta}$} & \multicolumn{2}{|c|}{ t test } & \multicolumn{2}{|c|}{ significance } \\
\hline & Sucrose & Glucose & Sucrose & Glucose & Sucrose & Glucose & Sucrose & Glucose \\
\hline constant & -0.30 & 0.22 & & & -0.456 & 0.379 & 0.658 & 0.713 \\
\hline$\alpha$-amylase & 0.23 & 0.31 & 0.81 & 0.90 & 4.164 & 6.302 & 0.002 & 0.000 \\
\hline Standard error & 0.46 & 0.42 & & & & & & \\
\hline $\mathrm{R}^{2}$ & 0.658 & 0.81 & & & & & & \\
\hline \multicolumn{9}{|c|}{ ANOVA } \\
\hline & \multicolumn{2}{|c|}{ df } & \multicolumn{2}{|c|}{ MS } & \multicolumn{2}{|c|}{$F$ test } & \multicolumn{2}{|c|}{ significance } \\
\hline Regression & 1 & 1 & 3.74 & 6.89 & 17.34 & 39.721 & 0.002 & 0.000 \\
\hline Residual & 9 & 9 & 0.22 & 0.173 & & & & \\
\hline Total & 10 & 10 & & & & & & \\
\hline
\end{tabular}

\section{Discussion}

Chl $a$ as the reaction center of photosystems I and II in plants with $15 \mathrm{mg} \mathrm{MN} \mathrm{L}^{-1}$ was the highest. In addition, chl $b$ and carotenoids as the recipient pigments were the highest in this treatment. This shows the incremental effect of this treatment to protect the photosynthetic apparatus. The total chlorophyll content was the highest in this treatment. This index shows the more dry weight than other treatments (Muthuri et al., 2009). However, a photosynthetic index of chl $a / b$ introducing light adaptability of plant, and chl/carotenoid as determining the health of the photosynthetic apparatus had not any differences between treatments and the last indicator in all treatments were over five and it is a sign of health photosynthetic apparatus 137 days after planting.

The highest concentration of CM had a reducing impact on the photosynthetic apparatus, which the role of iron in the structure of $\mathrm{MN}$ with its highlighted magnetic effect. Van et al. (2013) stated that nanoparticles of chitosan could easily penetrate into the plant cell and increase the biological activity of cells. They referred to the important effect of chitosan nanoparticles on the biophysical characteristics of coffee plant such as increasing chlorophyll content and plant growth. Răcuciu and Creangă (2007b) applied ferofluids at low concentrations (less than $100 \mu \mathrm{l} \mathrm{l}^{-1}$ ) without electromagnetic treatment or any other magnetic field for corn seedling. They stated that super-paramagnetic effect (special effect of magnetic nanoparticles) on structures of photosynthetic enzymes might promote growth. Răcuciu and Creangă (2007a, b; 2009) and Răcuciu et al. (2009) used two types of magnetic nano-fluid of $\mathrm{Fe}_{3} \mathrm{O}_{4}$ These fluids were the uncoated or coated with tetra-methyl ammonium hydroxide and were used in petri dishes for germination of corn without the use of a magnetic field at a concentration of $50 \mu \mathrm{L} \mathrm{L}^{-1}$. They observed that plant height increased.

El Sayed (2014) reported incremental effect of magnetic water treatment on plant growth of Vicia faba and chls $a$ and $b$ and carotenoids, gibberellic acid and kinetin. As you know, kinetin (cytokinins) affects the protection and prevention of the chlorophyll degradation (Taiz and Zeiger, 2002). Farouk and Amany (2012) reported the incremental effect of spraying with chitosan $\left(250 \mathrm{mg} \mathrm{L}^{-1}\right)$ on chl $a$ and $b$ in the pea. They interpreted that internal level of cytokinins increases and this stimulates the synthesis of chl due to the role of amino groups in chitosan. Since, the magnetic field is the earth's natural feature, plants and other living creatures in their own life respond to the magnetic field.

In particular, the electromagnetic spectrum of solar radiation simulates plant growth by the process of photosynthesis. The possible mechanism is the change of the balance of the plant electrostatic system at the level of the cell membrane, which is the primary location for each inhibiting or increasing the plant growth (Radhakrishnan and Kumari, 2012). Therefore, the role of superparamagnetic nano-particles in our experiments can be interpreted based on the Earth's magnetic field effect.

The MN (15 mg L $\mathrm{m}^{-1}$ ) caused that the amount of starch in tissues of the bulblet scales to be the highest. Although, the starch using the highest concentration of MN showed the highest in the bulblet before vernalizing, but sucrose in the vernalized yearling bulblets of plants that were treated with $5 \mathrm{mg} \mathrm{CM} \mathrm{L}{ }^{-1}$ was higher. This effect was also observed in glucose, and even it showed a significant increase compared to $10 \mathrm{mg} \mathrm{MN} \mathrm{L}^{-1}$.

Furthermore, the amount of fructose in both types of chitosan supplements was higher. Activities of amylases with CM supplement were higher. Therefore, it can be interpreted that magnetic chitosan nanoparticles caused higher starch storage after vernalization, and the amount of starch breakdown into glucose and the synthesis of sucrose was due to lower enzyme $\alpha$-amylase activity and likely took place gradually and during emergence and growth of shoots and flower bulb production. Furthermore, regardless of the type and concentration of supplements, both of them caused to increase the bulb quality compared to the control treatment.

It has been reported that magnetic field increased the sugar content in the roots of sugar beet (B. vulgaris) and gluten content in wheat (Triticum aestivum) (Dhawi et al., 2009). Radhakrishnan and Kumari (2012) referred that the pulsed magnetic field affected by an increase in $\alpha$ - and $\beta$-amylase activities in soybean. Starch and other sugars and proteins (enzymes) as products of photosynthesis are 
transferred to storage organs (flowers, seeds or bulbs). The sugar storage in lily bulb is mostly as starch, it means that the photosynthetic materials (starch) are transferred from shoot to bulb or bulblet.

The experiment shows that plants treated with $\mathrm{MN}$ by appropriate concentration $\left(15 \mathrm{mg} \mathrm{L}^{-1}\right)$ had the most storage of starch more than the amount reported for Lilium in scientific articles (Miller and Langhans, 1990). This compound, in addition to being as an organic supplement produced from chitosan also contains magnetic iron. Iron is an essential element that has an important role for optimal cell growth (He et al., 2011).

El Sayed (2014) reported that magnetic water treatment increases photosynthetic yield and the content of glucose and sucrose in the leaves and stems of beans and entire plants. In addition, the positive effect of chitosan on plant growth may be due to its effect on increasing the content of phosphorus. Phosphorus is an essential element in the biosynthesis and transport of carbohydrates during cell division and the formation of DNA and RNA (Farouk and Amany, 2012).

Due to the combined effects of magnetism, chitosan and iron, MN dramatically improves photosynthetic structures, photosynthesis, mobilization of assimilates and storage of starch, so that Takeda et al. (1983) announced when substrate (starch) increases the activity of amylases especially $\alpha$-amylase increases.

\section{Conclusions}

In conclusion, it can be suggested that magnetic nanocomposite to be used as a chelating compound in a Hoagland solution, because, in addition to the combined effects of chitosan (with the chelating role) and magnetism (effect on the activity of photosynthetic enzymes and enhancement of photosynthesis), supplies the iron demand in the plant. Based on the investigated effects on the starch amounts as a quality criterion in lily bulbs, magnetic nano-composite in a concentration of $15 \mathrm{mg} \mathrm{L}^{-1}$ in the Hoagland solution without iron salts is recommended.

\section{Acknowledgment}

Author likes to thank Deputy of Research and Technology, Ornamental Plants Research Center, Horticultural Sciences Research Center for funding and supporting to report this paper.

\section{References}

ABADÍA，J.; VÁZQUEZ, S.; RELLÁN-ÁLVAREZ, R.; EL-JENDOUBI, H.; ABADÍA, A.; ÁLVAREZFERNÁNDEZ, A.; LÓPEZ-MILLÁN, A.F. Towards a knowledge-based correction of iron chlorosis. Plant Physiology and Biochemistry, v.49, n.5, p.471-482, 2011.

EL SAYED, H.E.S.A. Impact of magnetic water irrigation for improve the growth, chemical composition and yield production of broad bean (Vicia faba L.) plant. American journal of experimental agriculture, v.4, n.4, p.476, 2014.
CASTRO, A.J.; CLÉMENT, C. Sucrose and starch catabolism in the anther of Lilium during its development: a comparative study among the anther wall, locular fluid and microspore/ pollen fractions. Planta, v.225, n.6, p.1573-1582, 2007.

CHANDRA, S.; CHAKRABORTY, N.; DASGUPTA, A.; SARKAR, J.; PANDA, K.; ACHARYA, K. Chitosan nanoparticles: a positive modulator of innate immune responses in plants. Scientific Reports, v.5, p.15195, 2015.

CHANG, Y.C.; CHEN, D.H. Preparation and adsorption properties of monodisperse chitosan-bound $\mathrm{Fe}_{3} \mathrm{O}_{4}$ magnetic nanoparticles for removal of $\mathrm{Cu}$ (II) ions. Journal of Colloid and Interface Science, v.283, n.2, p.446-451, 2005.

DHAWI, F.; AL-KHAYRI, J.M.; HASSAN, E. Static magnetic field influence on elements composition in date palm (Phoenix dactylifera L.). Research Journal of Agriculture and Biological Sciences, v.5, n.2, p.161-166, 2009.

DOEHLERT, D.C.; DUKE, S.H.; ANDERSON, L. B-amylases from alfalfa (Medicago sativa L.) roots. Plant physiology, v.69, n.5, p.1096-1102, 1982.

FAROUK, S.; AMANY, A.R. Improving growth and yield of cowpea by foliar application of chitosan under water stress. Egyptian Journal of Biology, v.14, n.1, p.14-16, 2012.

GOMIS, D.B.; TAMAYO, D.M.; ALONSO, J.M. Determination of monosaccharides in cider by reversedphase liquid chromatography. Analytica Chimica Acta, v.436, n.1, p.173-180, 2001.

HASSAN, M.A.; OMER, A.M.; ABBAS, E.; BASET, W.M.; TAMER, T.M. Preparation, physicochemical characterization and antimicrobial activities of novel two phenolic chitosan Schiff base derivatives. Scientific Reports, v.8, n.1, p.11416, 2018.

HE, S.; FENG, Y.; REN, H.; ZHANG, Y.; GU, N.; LIN, $\mathrm{X}$. The impact of iron oxide magnetic nanoparticles on the soil bacterial community. Journal of Soils and Sediments, v.11, n.8, p.1408-1417, 2011.

HOAGLAND, D.R.; ARNON, D.I. The water-culture method for growing plants without soil. California Agricultural Experiment Station, 347 (2nd edit), 1950.

KAH, M.; KOOKANA, R.S.; GOGOS, A.; BUCHELI, T.D. A critical evaluation of nanopesticides and nanofertilizers against their conventional analogues. Nature Nanotechnology, p.1, 2018.

KANG, Y.S.; RISBUD, S.; RABOLT, J.F.; STROEVE, P. 1996. Synthesis and characterization of nanometer-size $\mathrm{Fe}_{3} \mathrm{O}_{4}$ and $\gamma-\mathrm{Fe}_{2} \mathrm{O}_{3}$ particles. Chemistry of Materials, v.8, n.9, p.2209-2211, 1996. 
KIM, S.H.; NIEDZIELA, JR.C.E.; NELSON, P.V.; DE HERTOGH, A.A.; SWALLOW, W.H.; MINGIS, N.C. Growth and development of Lilium longiflorum 'Nellie White' during bulb production under controlled environments: I. Effects of constant, variable and greenhouse day/night temperature regimes on scale and stem bulblets. Scientia Horticulturae, v.112, n.1, p.89-94, 2007a.

KIM, S.H.; NIEDZIELA, JR.C.E.; NELSON, P.V.; DE HERTOGH, A.A.; SWALLOW, W.H.; MINGIS, N.C. Growth and development of Lilium longiflorum 'Nellie White' during bulb production under controlled environments: II. Effects of shifting day/night temperature regimes on scale bulblets. Scientia Horticulturae, v.112, n.1, p.95-98, $2007 \mathrm{~b}$.

LICHTENTHALER, H.K. [34] Chlorophyll and carotenoids: pigments of photosynthetic biomembranes. In Methods in enzymology Academic Press, v. 148, p. 350382. 1987.

LICHTENTHALER, H.K.; BUSCHMANN, C. Chlorophyll and carotenoids: Measurement and characterization by UV $\square$ VIS spectroscopy. Current protocols in food analytical chemistry, 2001.

MILLER, W.B.; LANGHANS, R.W. Low temperature alters carbohydrate metabolism in Easter lily bulbs. HortScience, v.25, n.4, p.463-465, 1990.

MUTHURI, C.W.; ONG, C.K.; CRAIGON, J.; MATI, B.M.; NGUMI, V.W.; BLACK, C.R. Gas exchange and water use efficiency of trees and maize in agroforestry systems in semi-arid Kenya. Agriculture, Ecosystems and Environment, v.129, n.4, p.497-507, 2009.

NIEDZIELA, JR.C.E.; KIM, S.H.; NELSON, P.V.; DE HERTOGH, A.A. Effects of N-P-K deficiency and temperature regime on the growth and development of Lilium longiflorum 'Nellie White'during bulb production under phytotron conditions. Scientia Horticulturae, v.116, n.4, p.430-436, 2008.

NIELSEN, T.H.; DEITING, U.; STITT, M. A [ $\beta]$-amylase in potato tubers is induced by storage at low temperature. Plant Physiology, v.113, n.2, p.503-510, 1997.

RĂCUCIU, M.I.H.A.E.L.A.; MICLĂUŞ, S.I.M.O.N.A.; CREANGĂ, D.E. The response of plant tissues to magnetic fluid and electromagnetic exposure. Romanian Journal of Biophysics, v.19, n.1, p.73-83, 2009.

RĂCUCIU, M.; CREANGĂ, D.E. Influence of waterbased ferrofluid upon chlorophyll in cereals. Journal of Magnetism and Magnetic Materials, v.311, n.1, p.291294, 2007a.
RACUCIU, M.; CREANGA, D.E. TMA-OH coated magnetic nanoparticles internalized in vegetal tissue. Romanian Journal of Biophysics, v.52, n.3/4, p.395, $2007 b$.

RADHAKRISHNAN, R.; KUMARI, B.D.R. Pulsed magnetic field: a contemporary approach offers to enhance plant growth and yield of soybean. Plant Physiology and Biochemistry, v.51, p.139-144, 2012.

SHAFIEE-MASOULEH, S.S; HATAMZADEH, A.; SAMIZADEH, H.; RAD-MOGHADAM, K. Enlarging bulblet by magnetic and chelating structures of nanochitosan as supplementary fertilizer in Lilium. Horticulture, Environment and Biotechnology, v.55, n.6, p.437-444, 2014.

SHIN, K.S.; CHAKRABARTY, D.; PAEK, K.Y. Sprouting rate, change of carbohydrate contents and related enzymes during cold treatment of lily bulblets regenerated in vitro. Scientia Horticulturae, v.96, n.1-4, p.195-204, 2002.

SIDDAIAH, C.N.; PRASANTH, K.V.H.; SATYANARAYANA, N.R.; MUDILI, V.; GUPTA, V.K.; KALAGATUR, N.K.; ... SINGH, B.P. Chitosan nanoparticles having higher degree of acetylation induce resistance against pearl millet downy mildew through nitric oxide generation. Scientific Reports, v.8, n.1, p.2485, 2018.

TAIZ, L.; ZEIGER, E. Plant Physiology, Sinauer Associates. 2002.

TAKEDA, C.; TAKEDA, Y.; HIZUKUR, S. Physicochemical properties of lily starch. Cereal Chemistry, v.60, n.3, p.212-216, 1983.

THOIRON, S.; BRIAT, J.F. Differential expression of maize sugar responsive genes in response to iron deficiency. Plant Physiology and Biochemistry, v.37, n.10, p.759$766,1999$.

VAN, S.N.; MINH H.D.; ANH D.N. Study on chitosan nanoparticles on biophysical characteristics and growth of Robusta coffee in green house. Biocatalist and Agricultural Biotechnology, v.2, n.4, p.289-294, 2013.

WU, L.; LIU, M. Preparation and properties of chitosancoated NPK compound fertilizer with controlled-release and water-retention. Carbohydrate Polymers, v.72, n.2, p.240-247, 2008.

ZHANG, B.; HU, R.; SUN, D.; WU, T.; LI, Y. Fabrication of chitosan/magnetite-graphene oxide composites as a novel bioadsorbent for adsorption and detoxification of $\mathrm{Cr}$ (VI) from aqueous solution. Scientific Reports, v.8, n.1, p.15397, 2018 